\title{
Envisioning a Democratic Culture of Difference: Feminist Ethics and the Politics of Dissent in Social Movements
}

\author{
Sheena J. Vachhani ${ }^{1}$ (D)
}

Received: 9 July 2018 / Accepted: 13 December 2019 / Published online: 24 December 2019

(c) The Author(s) 2019

\begin{abstract}
Using two contemporary cases of the global \#MeToo movement and UK-based collective Sisters Uncut, this paper argues that a more in-depth and critical concern with gendered difference is necessary for understanding radical democratic ethics, one that advances and develops current understandings of business ethics. It draws on practices of social activism and dissent through the context of Irigaray's later writing on democratic politics and Ziarek's analysis of dissensus and democracy that proceeds from an emphasis on alterity as the capacity to transform nonappropriative self-other relations. Therefore, the aims of the paper are: (i) to develop a deeper understanding of a culture of difference and to consider sexual difference as central to the development of a practical democratic ethics and politics of organizations; (ii) to explore two key cases of contemporary feminist social movements that demonstrate connected yet contrasting examples of how feminist politics develops through an appreciation of embodied, intercorporeal differences; and (iii) to extend insights from Irigaray and Ziarek to examine ways in which a practical democratic politics proceeding from an embodied ethics of difference forms an important advancement to theorising the connection between ethics, dissent and democracy.
\end{abstract}

Keywords Alterity $\cdot$ Democracy $\cdot$ Difference $\cdot$ Feminism $\cdot$ Feminist ethics $\cdot$ Irigaray $\cdot$ Radical politics $\cdot$ Gender $\cdot$ Ziarek

\section{Introduction}

Whilst the field of business ethics and corporate social responsibility (CSR) have made strides in considering gender, Grosser and Moon (2017) note there is rarely explicit reference or substantive exploration of feminist theory to understand gendered differences and issues in business ethics. As Borgerson (2007, p. 477) attests, "feminist ethics has been consistently overlooked, misunderstood, and improperly applied within business ethics and corporate social responsibility". Feminist ethics offers rich theoretical and conceptual resources for understanding and representing diverse interests, effectively critiquing corporate business ethics, corporate sovereignty and offering alternative forms of ethics for organizations (Burton and Dunn 1996; Liedtka 1996; Rhodes 2016) by exploring the intersections between relationships, responsibility and experience (Borgerson

Sheena J. Vachhani

s.vachhani@bristol.ac.uk

1 Department of Management, School of Economics, Finance and Management, University of Bristol, Howard House, Queens Avenue, Bristol BS8 1SD, UK
2007). In particular, these perspectives offer insight into the politics of difference, namely how gendered differences are constructed and how they enable and constrain the dynamics of corporate power and privilege in organizations (Karam and Jamali 2015).

To translate this further into organizational terms, feminist ethics and politics offer ways of disturbing organizations, pushing beyond constructed categories assigned to us, such as gender, race and class, and engaging in a politics of disturbance of organizational order "through critique, resistance and opposition to the self-interested sovereignty of business and to the pretense of corporate immutability in the name of capitalism" (Rhodes 2014, p. 726). Importantly, this provides a practical ethics for understanding dynamics of oppression and discrimination that go beyond narrowly defined and reductive notions of gender in mainstream business ethics and corporate social responsibility literature, such as the focus on instrumental approaches to women's empowerment, gender equality and corporate leadership (Grosser and Moon 2017; Grosser and McCarthy 2018).

This paper thus contributes to debates around democracy and business ethics by showing how dissent, in the form of activist, grassroots organizations, collectives and networks, 
representing different individuals and groups are able to effectively resist and how feminist movements rethink gender, race and class differences and the challenges this entails. "This ethics finds practical purchase in forms of dissent that redirect power away from centres of organized wealth and capital, returning it to its democratically rightful place with the people, with society" (Rhodes 2016, p. 1501). A practical, democratic business ethics on this basis is where the actions and practices of social justice groups hold institutions and corporations to account and challenge and disrupt corporate sovereignty (Rhodes 2016).

The theoretical critique developed here draws on the feminist philosophy of Luce Irigaray and Ewa Plonowska Ziarek whose work on dissensus and radical democracy offers important theoretical perspectives for a practical and gendered, democratic organizational politics. Irigaray sees "the contemporary ethical project as a recall to difference, rather than equality, to difference between women and men - that is, sexual difference" (Fermon 1998, p. 120). Irigaray contends that overlooking the symbolic organization of power (Fermon 1998) reifies the subordinated position of the feminine and if democracy is to be real, consideration needs to be given to the status of women in democratic thinking rather than recourse to a universalised, masculine subject of democracy. Ziarek (2001, p. 172) develops and extends Irigaray's concern for a radical female imaginary and operationalises the idea that,

Although women have won the formal rights of citizenship in Western democracies, the liberal discourse of rights has not yet been transformed to express a culture of sexual difference. Without a culture of difference constructed within the larger horizon of economic equality, women, Irigaray argues, are caught in a double bind between 'the minimum of social rights they can obtain... and the psychological or physical price they have to pay for that minimum'.

In this sense, Irigaray and Ziarek both enable the development of a practical democratic ethics whereby "women under these conditions require imaginative ways to reconfigure the self, to subvert the melancholy and regression of masculinist economies and envisage a future in which women would not be ashamed of the feminine, would experience it as a positivity worth emulating" (Fermon 1998, p. 120). In light of the challenges many women face to be heard and the effects economic cuts have on the most vulnerable, women's democratic participation, modes of dissent and the complexities surrounding women's differences continue to be an important and necessary conversation for advancing ethical debates.

Therefore, the contributions of the paper are: (i) to develop a deeper understanding of the politics of difference and to consider sexual difference as central to the development of a democratic business ethics and politics of organizations; (ii) to explore two key cases of contemporary women's social activism that demonstrate connected yet contrasting examples for how feminist politics develop through an appreciation of embodied, intercorporeal differences and a commitment to holding organizations and institutions to account built on a nonappropriative relation to the Other (Pullen and Rhodes 2014; Ziarek 2001), namely the recent global \#MeToo movement (see Tyler 2018; Vachhani and Pullen 2019) and Sisters Uncut collective, a UKbased direct action collective; and (iii) to extend insights from Irigaray and Ziarek to examine ways in which a radical democratic politics proceeding from an embodied ethics of difference forms an important advancement to theorising the connection between ethics, dissent and democracy.

The paper is structured as follows: firstly, the politics of difference are explored and the implications this has for thinking about dissensus, resistance and activism. This is done in the context of business ethics and CSR and outlines the importance of considering sexual difference. Following this, Irigaray's ethics of sexual difference (Irigaray 1993a) and Ziarek's ethics of dissensus are developed as a way of rethinking the possibilities of democratic engagement with sexual difference at its heart. Ziarek challenges and builds on Irigaray's work to suggest that a more radicalized view is needed if sexual difference still has a political future and ethical relevance for feminism. Two important examples of grassroots, social activist groups are then discussed that illustrate feminist activism based on recognition and embodied ethics of difference. The paper ends by offering a series of observations for developing a democratic culture of difference and what this brings to democratic business ethics (Rhodes 2016) that furthers our understanding of ethics, dissensus and radical democracy.

\section{The Politics of Difference-Conceptualising Gender Differences and Sexual Difference in the Context of Dissent, Ethics and Democracy}

Feminist, poststructuralist approaches in particular highlight ways in which categories of the feminine and feminine subjectivity and difference become subordinated and constructed in relation to masculine subjectivity (Irigaray 1993a). This subordination of the feminine raises crucial ethical questions that foreground discussions of democratic ethics and feminist politics, namely: What political future(s), if any, does sexual difference have? (Cheah and Grosz 1998, p. 3). What is contended here is that the politics of difference, especially sexual difference, has not been sufficiently attended to in the ethics literature and that feminist ethics, 
through Irigaray and Ziarek, enriches a reflexive rethinking of dissent and democratic action in organizations.

How difference is constructed in business ethics and CSR literature is intimately related to positions of power and needs to be understood in relation to the political and social contexts in which organizations function (Grosser 2016; Grosser and Moon 2005; Karam and Jamali 2015; Keenan et al. 2014). For example, gender equality and women's empowerment have become popularised as corporate ethical discourses and as part of mainstream CSR agendas, mobilised in terms of competitive advantage and legitimised by the business case, namely economic arguments for improving profitability of organizations (Grosser and Moon 2005; Grosser 2016). This agenda has been limiting and conceives of gender difference in narrow, reductive terms and the rise of corporate power and corporate discourses of gender equity provides challenges to feminist movements working to resist these reductive discourses (Grosser and McCarthy 2018).

Critiques of corporate business ethics and managerial discourses suggest that differences between individuals and groups are constructed and brought into being in order to be appropriated (Zanoni et al. 2010). Tyler (2018, p. 49) notes these reificatory processes render lived multiplicity, difference and intersectional complexity knowable and therefore manageable categories and characteristics ready to be coopted as organizational resources. Thus, difference can be defined as "Those points of disidentification and dissimilarity that come to be experienced or perceived as socially, politically and ethically significant" (Tyler 2018, p. 52) that manifest through context-specific processes (Zanoni et al. 2010) and which reflect, sustain or transform relations of power.

Within and evolving from these debates has been a concern with sexual difference (Fotaki et al. 2014; Oseen 1997; Pullen and Vachhani 2018; Vachhani 2012) that questions the philosophical, political, practical and social basis on which gender differences are demarcated and constructed within the context of phallocratic and patriarchal culture, namely the prevalence of a singular, hegemonic masculine subject as opposed to a welcoming otherness or alterity (Fermon 1998). The latter is premised on an inter-corporeal understanding of alterity as situated within embodied relations of mutual vulnerability and ethical openness (Pullen and Rhodes 2015; Dale and Latham 2015). In Grosz's terms, "sexual difference entails the existence of a sexual ethics, an ethics of the ongoing negotiations between beings whose differences, whose alterities, are left intact but with whom some kind of exchange is nonetheless possible" (Grosz 1994, p. 192). Thus, what becomes important are the lived, social dimensions of sexual difference, not as biological differences between bodies but as the ontological status of the sexed body.

\section{Irigaray and an Ethics of Sexual Difference}

Irigaray's work has been explored in management and organization studies to consider the conceptual potential of a feminist psychoanalytic approach to gendered and sexual differences across a variety of contexts such as leadership, academia and writing practices (Fotaki 2011; Fotaki et al. 2014; Pullen and Vachhani 2018; Vachhani 2018). Fotaki $(2011,2013)$ shows how sameness and difference become reinforced in academia by masculine discourses that centre around the presence or absence of the phallus that suggests the existence of a singular, hegemonic masculine subject that is unable to recognise a feminine subject. Oseen (1997) and Pullen and Vachhani (2018) challenge corporate women's leadership discourses in order to enable the creation of "a space for women other than as imitation men or excavated women" (Oseen 1997, p. 170).

In comparison, Vachhani (2012) discusses sexual difference by addressing ethical and political dilemmas of the subordination of the feminine in organizations. Recent discussions turn to Irigaray to write differently using feminine writing or feminist écriture, that does not suppress and conceal possibilities for understanding difference as a recognition of the feminine (Fotaki et al. 2014; Höpfl 2000; Vachhani 2018). This approach insists on the transformative and activist potential of feminine writing one that offers a practical politics for changing organizations.

Despite these advances, less attention has been paid to Irigaray's later work that focuses attention on civil rights, responsibilities and democracies. Je, Tu, Nous (Irigaray. 1993b), Thinking the Difference (Irigaray 1994), and Democracy Begins Between Two (Irigaray 2000b), in particular, draw on the development and practical implications of a theory of sexual difference for feminist politics, sexed rights and democratic culture (Ziarek 2001). Debates surrounding the politics of difference have arguably paid more attention to differences between groups which have resulted in the problematic homogenisation of identity and culture of any group to which particular or special rights might be ascribed (Deutscher 2002; see Ashcraft 2009; Grosser 2016; Tyler 2018). As Hekman (1999, p. 11) discusses, a culture of difference involves the idea that differences involve power and, "If we challenge those differences by asserting their opposites, the challenge is necessarily parasitic on the difference itself, not an escape from it." Drawing on Michele Le Doeuff, Deutscher (2002, p. 9) explains that "respect for cultural and sexual difference is regularly selective, opportunist, and cynical". Thus, for Irigaray amongst others, sameness and difference need to be reconceived in order to pursue an ethical recognition of political, social and democratic difference to enable social change. Irigaray's work is important in this regard as she argues for a culture of difference for 'a self-defined woman who would not be satisfied 
with sameness, but whose otherness and difference would be given social and symbolic representation" (Whitford 1991, pp. 24-25; Irigaray 2000a; Martin 2003) and endorse "political equality while maintaining concerns about its terms" (Deutscher 2002, p. 9).

It is important to note critiques of Irigaray's work which have primarily centred around being read as essentialist, elitist and inaccessible (Whitford 1991; Deutscher 2002). Despite these critiques, many have read Irigaray's metonymic and poetic writing as figurative rather than literal such that charges of biological essentialism are seen more as a strategic, rhetorical gesture to instal the embodied feminine subject into the text rather than a reflection of biological femininity or womanhood (Fuss 1992; Whitford 1991; Vachhani 2014). Taking what Fuss calls 'the risk of essentialism', that one could argue is largely tactical, Irigaray attempts to inscribe difference and conjure up an 'other woman'. Butler (1993, p. 35) notes that "Irigaray's task is to reconcile neither the form/matter distinction nor the distinctions between bodies and souls or matter and meaning. Rather, her effort is to show that those binary oppositions are formulated through the exclusion of a field of disruptive possibilities... those binaries, even in their reconciled mode, are part of a phallogocentric economy that produces the 'feminine' as its constitutive outside".

Thought of in this way, an ethics of sexual difference creates new conditions for the articulation of difference (Gatens 1999) in the context of business ethics rather than invoking a monolithic, binary notion of gendered differences between men and women that reasserts or re-inscribes essentialist presumptions or reproduces gendered stereotypes. This calls for emphasis on the fluidity of sexual difference alongside race, class and other differences where such a construction requires an openness to alterity in the context of democracy (Weiss 1998; Ziarek 2001). Fermon (1998, p. 120) writes that "Irigaray warns that if civil and political participation is construed in overly narrow terms, if focus is on economic or judicial 'circuits' alone, we overlook the symbolic organization of power-women risk losing 'everything without even being acknowledged"'. Instead an interval of recognition, which concerns how alterity is not about subsuming the Other, can expand the political and include the concerns and activities of different groups of women (Fermon 1998), through democratic organizational practices and settings such as social movements. Recognition in this sense is the "embodied, practical and cooperative character of the selfother relation" (Harding et al. 2012, p. 57, also cited in Tyler 2018 p. 50) generated through embodied practice.

In Democracy Begins Between Two, Irigaray's (2000b) concern is how to operationalise this approach to sexual difference and situate it within social [and organizational] practice. She initiated a working collaboration with the Commission for Equal Opportunities in Emilia-Romagna,
Italy to challenge civic rights, citizenship and otherness. This enables rethinking dissent and resistance as democratic engagement and action in the following way: How women's movements centre around challenging different forms of political life and their related power relations and values, are about modifying women's status within democracy. However, "when these same movements aim simply for a change in the distribution of power, leaving intact the power structure itself, they are resubjecting themselves, deliberately or not, to a phallocratic order. The latter gesture must of course be denounced, and with determination, since it may constitute a more subtly concealed exploitation of women." (Irigaray 1985b, p. 81; Irigaray 1985a). This approach aims to challenge the context and framework of difference to reconceptualise its bounds and rethink a model of subjectivity (Irigaray 2000b). It also provides important insight into the way in which difference can be tactically, reflexively mobilised in a rethinking of radical democracy in the context of organizational ethics. Ziarek develops this point in Irigaray's work to argue for an ethics of dissensus to which I now turn.

\section{Ziarek and an Ethics of Dissensus}

If culture, under patriarchy, is concerned with the existence of one subject, the logic of the one and the feminine as its shadow of the other, then a radicalized feminine symbolic or female imaginary must, in part, suspend this state. Sexual difference is then not the positive recovery of truth but "an articulation of the disjunctive temporality characteristic of the emergence of the new modes of life" (Ziarek 2001, p. 158), new imaginary and symbolic identifications that offer the opportunity for change, which can be seen in the cases discussed below. Therefore, what is at stake is an ethics and politics of recognition, proceeding from an embodied, tactical mobilisation of difference. Irigaray brings this to the fore by claiming a space for a radical female imaginary (Ziarek 1998; Dale 2001) which is developed and extended by Ziarek (2001).

Ziarek's (2001, p. 1) development of an ethics of dissensus refers to the "irreducible dimension of antagonism and power in discourse, embodiment, and democratic politics" where "An ethics of dissensus does not transcend political and subjective antagonisms...but rather articulates the difficult role of responsibility and freedom in democratic struggles against racist and sexist oppression" (Ziarek 2001, p. 2). Ethics can be read as the dilemma between freedom, responsibility and obligation and, for Ziarek, an ethics that concerns an "ethos of becoming" and "ethos of alterity" which lead not only to a nonappropriative relation to the Other, as Levinas argues (see Rhodes 2016), but considers how obligation based on respect for such an alterity and accountability for the Other "can motivate resistance and 
the invention of...new modes of life" (Ziarek 2001, p. 2). Thus, freedom can be redefined as relational and understood through the ethical and political significance of sexuality and embodiment "as an engagement in transformative praxis motivated by the obligation for the Other" (Ziarek 2001, p. 2) that moves us beyond the binary relation of freedom and responsibility.

Ziarek's work is of importance here for business ethics literature because it seeks to understand ethics as a contested terrain in a way that does not occlude the role of sexual and racial differences. To summarise, rather than seeking ethical resolution or resolving antagonistic relations of power, ethics concern embodied relations of dissent that can motivate resistance and an attention to alterity that results in a nonappropriative, nonviolent relation to the Other. This results in seeing ethics as a contested terrain, one that contests the disembodied notion and universalising tendencies of democratic citizenship and addresses the tensions "between ethical responsibility for the Other and democratic struggles against domination, injustice, and inequality, on the one hand, and internal conflicts within the subject, on the other" (Ziarek 2001, p. 3). An ethics of dissensus is thus about how we account for the plurality and conflicts of irreducible differences such as class, race and gender which form a more suitable basis for understanding radical democracy and the antagonisms and dissent that it depends on. bell hooks (1996, cited in Ziarek 2001, p. 173) notes that critiquing the universal democratic citizen is not the rejection of common bonds or commonality "but that we want to find the basis of commonality in something other than a notion of shared experience or common oppression".

To distinguish Ziarek and Irigaray further, Ziarek critiques Irigaray's inability to address the antagonistic difference among women to draw on a broader, more radicalized notion of sexual difference, one that is more dynamic and open to transformation. Such a theory enables thinking about sexual difference in futural terms and "as a condition of becoming" (Ziarek 2001, p. 151; Pullen et al. 2017).

Using Irigaray's conceptualisation of the negative, Ziarek refers to the work of "disappropriation," where "the assumption of sexual difference reveals the limits of the symbolic positions rather than an identification with a positive identity" (Ziarek 2001, p. 153). The labour of the negative entails how we are never the whole of the subject: "I is never simply mine in that it belongs to a gender...I am objectively limited by this belonging. The reluctance to recognize the importance of sexual difference seems to me to derive from this negative in the self and for the self it entails." (Irigaray 1996, p. 106). In this sense, Irigaray engages in a politics of impossible difference (Deutscher 2002) where the negative is "the condition of the actualization of the negative in the subject - what she calls 'taking the negative upon oneself"" and "reveals the internal division and self-limitation of the sexed subject" (Ziarek 2001, p. 153). This marks sexual difference not as a universalised particularity but where "the assumption of sexual difference reveals the limits of the symbolic positions rather than an identification with a positive identity" (Ziarek 2001, p. 153). This recognition of the negative means challenging stereotypes of gender, race and class and 'norms' that become naturalised and homogenised in pursuit of a universal democratic subject. So, it is not simply the recognition of the rights of women to construct their own political identities, as advocated by Irigaray, but a broader and more fundamental contestation of the abstract and universalizing subject of liberal citizenship. This echoes Nancy Fraser's notion of political justice, which combines the politics of redistribution, such as economic redistribution, with the cultural claims of difference (Ziarek 2001).

Negative or impossible sexual difference must become radicalized and foregrounded such that "'the impossible' - contradictions, conflicts, incompletion -in the formation of all identities, the labor of the negative in sexual difference prevents the reification of the existing gender and racial stereotypes into political or 'natural' norms, thus opening the possibility of their refiguration" (Ziarek 2001, pp. 153-154). This radicalized view focuses not on the transformation of existing gender identities which would reproduce heterosexual, middle-class subjectivities as political norms but emphasises the impossible as the limit of all political positions (Ziarek 2001). Thus, the ways in which proliferating differences become reified into disembodied political subjects is of crucial ethical concern if we are to advance a democratic business ethics (Rhodes 2016) based on restoring democratic action and dissent to individuals and groups that challenge the corporate status quo.

Having explored a number of theoretical claims around difference, notably sexual difference through Irigaray and Ziarek, the next section explains the methodology and two cases, the global \#MeToo movement and UK-based direct action collective Sisters Uncut, to suggest that a democratic feminist ethics built on the nonappropriative relation to the Other emerges out of contemporary feminist, social activist movements and from this we can learn lessons for understanding a radicalized sexual difference. Feminist activism furthers our understanding and potential for radical democratic organizational practices. This is premised on an intercorporeal understanding of alterity situated within embodied relations of mutual vulnerability and ethical openness (Pullen and Rhodes 2014; Dale 2001) and centralises the ethical and political significance of gendered readings of democracy.

\section{Methodological Engagement}

This paper draws on empirical sources from two illustrative cases of feminist, social movements, using online sources such as websites, news stories, online interviews with key 
individuals and commentaries to explore unique and contemporary examples of social activism from grassroots movements. Such a "methodology of dissent" exemplifies aspects of radical democracy and an ethics of dissent explored in the theoretical discussion above in complementary and contrasting ways. This methodological approach has also been termed a "netnography" (Kozinets 2015), which uses social science methods to explore the lived experiences of individuals and the ways in which online communities and networks create "networked sociality". Combining elements of ethnography and social media research, the aim of netnography is to understand how "individuals joined into networks partake in a complex world that not only reflects and reveals their lived experiences but is also, itself, a unique social phenomenon" (Kozinets 2015, p. 1). It focuses attention on new social forms advanced by online, virtual spaces of social interaction and what they make possible (Kozinets 2015, p. 1), combining archival and online communications.

Online access to social interaction "demonstrates an evolving ecosystem of social and individual data and captured and emergent communications" and "netnography is positioned somewhere between the vast searchlights of big data analysis and the close readings of discourse analysis' (Kozinets 2015, p. 4). This approach demonstrates the contested and shifting notions of community and collectives that underpin social movements and the potential for empowering and self-reflexive research designs in feminist research (Lather 1991; Harding 1987). I draw on elements of this approach to surface contentions, contradictions and tensions in feminist politics by analysing empirical sources from the online presence of feminist social movements. This provides a sense of their practices and how they enable rethinking dissent and protest, analysed through an awareness of sexual difference and in light of tensions in the shift from protest to engagement with the State and other institutions that many feminist social movements face (Walby 2011).

The analysis below offers narrative fragments and interpretations, not with the intention to present either illustrative case as an homogenous collective of voices but to use accounts, narrations and stories of their development into collectives as important sites of democratic action and engagement, contexts that are often neglected in discussions in business ethics and CSR. This involves recognition of different spaces of dissent and resistance and the fluid boundaries between spaces of activism-visible protests, online communication and virtual communities. Such an approach also necessitates exploring supportive and contradictory accounts; collaboration and contestation that shapes feminist social activism (see Just and Muhr 2018, for a methodological discussion of studying the Women's March). The cases were chosen for being prominent feminist and intersectional movements: \#MeToo as an example of a global phenomenon facilitated by its media presence and use of social media to organize (see Ozkazanc-Pan 2018); and Sisters Uncut for its focus on resistance against austerity at a national level in the UK, using local consensus-driven practices of democratic engagement. The analysis below combines accounts of online and physical sociality in response to resisting sexual and gendered violence. It explores embodied relations in the form of visible events, imagery and iconography and the organizational dynamics and processes of ethical deliberation and democratic action.

\section{The \#MeToo Movement and Sisters Uncut- Dissent in Action at Global and National Levels}

To develop the first case, the recent \#MeToo movement has advanced a global platform for feminist politics (OzkazancPan 2018). \#MeToo gained momentum in 2017 as an international movement against assault and harassment and its global presence has made it an important example of feminist activism and politics. Devised as a grassroots campaign by Tarana Burke in 2006, the movement has been mobilised into consciousness raising and social activism aimed to empower women through empathy (see https://metoo mvmt.org/). As a pro-feminist movement, along with the Women's Marches (see Tyler 2018), it is a salient example of globalised feminist politics, with a remit for inclusion and celebration of difference. Whilst it can be said that these contemporary movements form part of a longer history of feminist activism (Vachhani and Pullen 2019) they also represent new and possibly unique moments in the development of feminist politics. Munro (2013) and Walby (2011) suggest that we may be in a fourth wave or "circuit" of feminism one that is mobilised by social media and the development of online, networked sociality.

The platform \#MeToo has gained, certainly in the Global North, included the presence of a number of social activists at the 2018 Oscars cefremony and association with a number of high profile women actors and flim directors (see Seales 2018). This demonstrated the movement's presence in an elite context and world stage. \#MeToo founder Tarana Burke along with other feminist activists were named Time's Person(s) of the Year for their consciousness raising efforts (Vachhani and Pullen 2019). The significant profile of the movement has catalysed debates on the backlash, effects and future of \#MeToo (Bennett 2018). This elicited a number of claims around a shift away from the emphasis on celebrity culture and the media industry, such as the case of Harvey Weinstein, towards shaping and critiquing cultural and societal narratives that shape behaviour in more varied organizational contexts. This entails moving away from focusing on individuals towards more nuanced, meaningful discussions of democratic organizational processes and collective 
women's agency (Ozkazanc-Pan 2018) that enables speaking out against harassment and oppression.

The purpose of the movement, espoused by Burke, has been to promote empathy and solidarity at an individual and collective level and to mobilise social change (see https:// metoomvmt.org/). Central to this claim is that the momentum gained by \#MeToo could change policies and law and promote the development of democratic practices, whether it be re-evaluating sexual harassment policies, destigmatising issues around sexual misconduct in organizations, or addressing policy-based changes around reporting and disclosure of harassment charges within workplaces. \#MeToo has raised a series of issues around women's agency, difference and how one kind of justice can overshadow other injustices. How \#MeToo relates to racial justice campaigns such as Black Lives Matter ${ }^{1}$ and \#SayHerName ${ }^{2}$ for example, is yet to be extensively studied as a way of working across intersectional concerns in activist movements. ${ }^{3}$ Rottenberg (2017, n.p.) explains, for Alicia Garza, another cofounder of Black Lives Matter, "The importance of 'Me Too' lies in the 'power of empathy, this power of connection, is really about empowering people to be survivors, to be resilient, and also to make really visible that sexual violence is not about people's individual actions, that this is a systemic problem'".

However, the public status of \#MeToo has raised criticisms around the groups of women neglected by such celebrated movements. For example, it has been accused of neglecting disenfranchised groups such as incarcerated women. Rottenberg (2017) offers another critical perspective, asking "Can \#MeToo go beyond white neoliberal feminism?" Given its inception in 2007 as a grassroots movement aimed to serve sexual assault survivors in underprivileged communities, its resurgence and contemporary shape has been charged with a surprising lack of focus on women from low socio-economic groups. Vachhani and Pullen (2019, p. 43) note, "It might even be that neoliberal feminism has

\footnotetext{
${ }^{1}$ See https://blacklivesmatter.com/.

2 Social movements such as \#SayHerName aim to build a substantial social media presence that link race-based justice movements. \#SayHerName was aimed at resisting police brutality against black women (see http://www.aapf.org/sayhername/) and to highlight the mistreatment of Black women in the criminal justice system in the United States. Art and poetry play a significant role in this movement. A particularly poignant example can be found on the \#SayHerName website, entitled: Ain't I A Woman?": The Poetics of \#SayHerName (2018 Week of Action), found at: http://www.aapf.org/sayhername -videos-1. Included in which is the powerful line "I cannot tell if I've been frightened to death or frozen alive".

${ }^{3}$ Patrisse Cullors, a founder of Black Lives Matter, and Tarana Burke have engaged in conversation about the role of class, gender and race-based activism and the issues they face as activists - See https://www.youtube.com/watch?v=_omi9JgKnnw.
}

thrived on shaming women to stay silent, fixing themselves rather than working collectively to address institutional and structural sexism and harassment in organizations". Social movements can only offer the possibilities of social change and transformation if they include women of all backgrounds and whilst such movements might create awareness they may not produce the appropriate tools for dialogue and reflection (Munar 2018; Vachhani and Pullen 2019).

Whilst \#MeToo has built social awareness and change, there are a number of challenges it raises around the politics of empathy (Pedwell 2014), that is who is offered empathy and what effects this has, alongside how to transfer discussion from consciousness raising to the institutional environment (Munar 2018). Rottenberg (2017, n.p.) notes how \#MeToo has shifted "debates about workplace norms" and "created new and surprising alliances". For example, the transnational reach of \#MeToo prompted a group of women lawyers to offer support to survivors in India, Pakistan and Bangladesh (Hemery and Singh 2019). One lawyer set up \#MeToo meetups and explained how it offers sisterhood to women and a forum to listen (Hemery and Singh 2019). However, the focus on individualism, especially the heroism of the individual's resilience may prevent mobilising people politically and collectively. This risks neglecting socio-economic and cultural structures and disarticulating the systemic nature of gendered and sexual violence (Rottenberg 2017). The recent focus on celebrity culture also means its historic roots to focus on low income and women vulnerable to violence have been overwritten. "From the outset, the movement had a very specific therapeutic and political vision that helps explain its affective pull, as well as why women feel empowered when speaking about their painful and often traumatic experiences. As Burke puts it: 'Me Too' is about 'using the power of empathy to stomp out shame."” (Rottenberg 2017, n.p.).

The primary tension is how to empower and embolden women to create ethical and responsible dialogue as collectives and communities that challenge the language of shame whilst recognising the systemic violence and intersecting systemic oppressions that underpin these acts (ibid 2017). For example, as Flynn (2019) notes, some indigenous cultures may not want to speak out for fear of inciting racism or further stereotyping men of their community. The complex dynamics of collective community over individual rights and the transnational dynamics of a complex, global feminist movement illustrate how democratic ethics is a contested terrain; one that engages in an ethics of dissensus as plurality and irreducible differences of class, race and gender (Ziarek 2001). This necessary contestation and deliberation calls for addressing the antagonistic differences between women and sexual difference as a "condition of becoming" (Ziarek 2001, p. 151). 
The second case, Sisters Uncut, is a direct action group against domestic violence that fights against different forms of oppression in the United Kingdom. Sisters Uncut provides a contrast to the \#MeToo movement which has been criticised for its focus on privileged groups of women. Their powerful feministo states that "austerity is a political choice" (http://www.sistersuncut.org/feministo/). ${ }^{4}$ Formed in 2014 by a group of intersectional feminists concerned with transforming society their feministo states,

As intersectional feminists we understand that a person's individual experience of violence is affected by interconnecting and mutually reinforcing systems of oppression....The systems of power and privilege in our society enable and protect the actions of perpetrators. This creates a cycle of violence, which can only be broken through transforming society. To those in power, our message is this: your cuts are violent, your cuts are dangerous, and you think that you can get away with them because you have targeted people who you perceive as powerless. We are those people. We are Sisters Uncut. We will not be silenced.

Sisters Uncut use direct action as a way of revealing structural problems, alternatives and solutions to tackling social issues that take many forms. By occupying spaces, hanging banners to draw attention to social issues, blocking bridges and calling out sexual harassment, "whatever form it takes, its purpose is to be disruptive". This forms a powerful way of effecting change through dissent and the embodied relations it entails where "Even if you don't see the exact result you want immediately, over time it can contribute to changing the conversation." (see http://www.sistersuncut.org/faqs/)

In contrast to \#MeToo, Sisters Uncut have engaged in a variety of resistance-based direct action protests aimed at challenging the status of women, such as: hijacking advertising on The London Underground to protest cuts to domestic violence services; occupying spaces (such as the Visitors Centre at Holloway women's Prison); flash mobbing Southwark Council offices; blocking Waterloo Bridge to protest cuts to refuge shelters and the disproportionate effects they have on black, disabled and migrant women ${ }^{5}$; and putting on community festivals. Their activities aim to shine light on issues affecting marginalised and vulnerable groups of women. They challenged the prison industrial complex by raising attention to the vulnerability of women at the Yarls Wood Detention Centre and reclaimed the Visitors Centre of Holloway Prison in 2017 (Holloway Prison was closed

\footnotetext{
${ }^{4}$ See also UK Uncut for a related anti-austerity grassroots movement using direct action and civil disobedience: https://www.ukuncut.org. uk/about/.

${ }^{5}$ For a list of news articles on action taken by Sisters Uncut in protest of austerity cuts, see http://www.sistersuncut.org/press/.
}

in July 2016) in protest of the erasure of the women who suffered there. ${ }^{6}$ The multiple axes of oppression addressed by Sisters Uncut, and campaigns such as \#SayHerName, briefly explored above, suggest a radical democracy aimed at embracing the embodied vulnerabilities of difference.

Sisters Uncut arguably offers a more localised and intersectional approach than \#MeToo. Their focus on collective, direct action is a way of changing how politics is done, sometimes being labelled as modern suffragettes (O'Hagan 2015). Groups have been formed across the country since high profile protests such as lying down on the red carpet at the premiere of the film Suffragette (Kwai 2015) and dying Trafalgar Square fountains blood red (Deardon 2015) alongside key, local achievements such as getting women's aid reinstated in Doncaster (Spratt 2016). This combination of intervening in public spaces and consciousness raising shows how contrasting avenues of democratic action forces people to confront issues and how politics considers women's issues (Spratt 2016, n.p.) aimed at creating greater insight and further action against the austerity cuts, state violence and the effects on different vulnerable groups of women.

Their aim is to create safe social spaces through values such as community accountability using an Accountability Toolbox with principles of transformative justice as a way of healing if a sister is harmed (see http://www.sistersunc ut.org/saferspaces/). They organize not around the sharing of particular feminist values but on the desire to campaign for better domestic violence services that recognise particular experiences and needs for women (see http://www.siste rsuncut.org/faqs/). The groups expressly state no hierarchy or leaders, use dialogue and consensus decision-making aimed to give members an equal say and meet to provide inclusive and supportive survivor-centred spaces for women, nonbinary, agender and gender variant people. ${ }^{7}$ Whilst there are criticisms of consensus building in relation to the cooptation of marginalised groups, consensus decision-making in this context is used as a practical tool for understanding embodied, ethical relations between individuals in pursuit of social change. This is opposed to consensus building in the context of liberal democracies that aims to elide or silence differences.

The ultimate aim of such an ethos is to foster dissensus at the heart of a culture of difference. The approach aims to cultivate and sustain creative and dynamic ways of fostering

\footnotetext{
${ }^{6}$ See http://www.gal-dem.com/services-not-sentences-sisters-uncut -occupy-holloway-womens-prison/ for further details on the activities of Sisters Uncut and the importance of remembering Holloway women's prison.

${ }^{7}$ For further details, see http://www.sistersuncut.org/faqs/.
} 
discussion, committed to finding solutions that are actively supported (see www.seedsforchange.org.uk/shortconse nsus), in a spirit of creating respectful dialogue between equals using techniques such as active listening, summarising and synthesis to achieve democratic decisions. A "Fishbowl spokescouncil" can be used, especially for large scale decision-making, an approach aimed to spread power for decision-making across small groups rather than concentrating power in the hands of individuals. ${ }^{8}$ One member states, "There's a lot of discussion and it isn't easy. Consensus is a lot harder than voting, straight up democracy or whatever. But, at the end of the day, people are happier in the long run" (Spratt 2016, n.p.).

One frustration noted by members is how Sisters are portrayed and the co-optation of femininity- "Those of us who do the media side of things are really aware of our image and how it has come across- that we are young and female - the media loves to fetishise young women-even when we do our big marches we'll have a really diverse group of people - in terms of ages and races - but the pictures that end up being taken and appear in mainstream media are of young, slim, white able-bodied women - that doesn't reflect all that we are" (Spratt 2016, n.p.; see also, Charles and Wadia 2017). Spratt surmises that this fetishization may stem from how anonymity is par for the course when engaging in direct action and how it is important that no sister gets more credit than another. One member states, "We see a lot of hierarchies in activism and in politics...it just perpetuates the kind of structure that we are trying to fight against. We are creating the world we want to see through the way we operate" (Spratt 2016, n.p.). This approach to democratic action, such as consensus-based approaches to decision-making, are used to challenge individuals vying for power, focusing on the structural problem rather than the individual- "It's not a challenge to the existing ego problems of politics if we replicate the very system that perpetuates it. We stay clear of the structures of traditional politics" and "it shows that it's the same tactics that need to be used everywhere-direct action." (Spratt 2016, n.p.). Spratt shows how inter-generational feminism plays a part with a strong presence of younger feminists passionate about domestic violence cuts and how they have also attracted those who would not have normally considered protest before joining.

\footnotetext{
${ }^{8}$ See www.seedsforchange.org.uk for an elaboration of techniques used for consensus decision-making in collectives and non-hierarchical activist groups. In a "Fishbowl spokescouncil" groups sit in an outer circle around spokes of a wheel. Groups are clustered behind the spokes and spokespeople (or spokes) from each group can feed back to the spokescouncil to reduce repetition of information. On the basis of the discussion, the spokescouncil can build a series of proposals which are discussed back in individual groups to check for agreement or change.
}

The focus on direct action and physical presence are core to Sisters Uncut in contrast with online activism prevalent in contemporary feminism: "But that's nothing in comparison to being in that room, being in that safe space, taking to the streets, using your body and just being there" (Spratt 2016, n.p.). Ziarek (2001, p. 153-154) notes that attention to the contradictions, conflict and incompleteness of identities thus opens up possibilities to reconfigure norms of gender, class and race and challenge the presumption of a universal democratic subject. Sisters Uncut shows how an intercorporeal understanding of alterity is enabled through embodied relations of dissent, mutual vulnerability and ethical openness (Pullen and Rhodes 2014).

These two cases demonstrate contrasting yet connected feminist social movements and their related power relations. However, whilst the advancement of women's rights help to modify women's status within democracy, they are also at risk of becoming institutionalised or absorbed into existing structures, thus leaving those structures intact and concealing further exploitation of women (Irigaray 1985b; Walby 2011). \#MeToo, as a movement beyond a hashtag, and Sisters Uncut engage in different forms of democratic ethics that challenge the context and framework for understanding difference, and more fully appreciate the complexities of women's differences within the structures they are a part (Irigaray 2000b). Sisters Uncut, in particular, provides insight into ways in which difference can be tactically and reflexively mobilised (Tyler 2018) through collective acts as a rethinking of radical democracy, by using shock, protests and accountability-driven practices. Global and local initiatives such as these cases may offer new modes of life, through imaginary and symbolic identifications, as Ziarek imagines. This manifests from an ethics of dissensus that recognises irreducible dimensions of power and political and subjective antagonisms (Ziarek 2001). \#MeToo and Sisters Uncut demonstrate a commitment to engage in an "ethos of alterity" which transforms practices of dissent informed by an "obligation for the Other" (Ziarek 2001, p. 2; Robinson 2000).

These two cases are connected in their engagement with embodied relations of dissent but offer contrasting contexts and methods by which democratic engagement is achieved to challenge institutional and structural social change. The paper now develops these arguments by examining their relevance for rethinking democratic organizational practices, especially for a democratic business ethics understood through sexual difference. Read through the earlier theoretical discussion of Irigaray and Ziarek, as Fermon (1998, p. 123) notes, the strategic challenge of sexual difference is a basis for democratic rights, that "will allow women space and time to generate an economy open to women's interactions with each other, to reach beyond sex-neutral citizenship to an open future". In contrasting and connected ways, 
the cases above speak to a democratic feminist politics built on nonappropriation of the other as a way of building and cultivating a culture of difference, but one that is always at risk of the appropriation of women's identities.

\section{Towards a Democratic Culture of Difference-Feminist Politics and Contemporary Ethics of Dissensus}

These cases highlight ways in which democratic dissent involves a tactical reassertion of difference, reasserting feminine difference in its multitude. This tactical reassertion politicises sexual difference and develops capacities for solidarity and democratic engagement not based on shared experiences of oppression that collapses or elides other forms of lived difference but on shared goals (Vachhani and Pullen 2019). When difference is managed, the problematic insistence on identity must lead to "taking stock of the constitutive exclusions that reconsolidate hegemonic power differentials, exclusions that each articulation was forced to make in order to proceed" (Butler 1993, p. 118). This returns us to two key questions that have wider relevance for feminist organization studies and feminist ethics: How do feminist politics expand the terrain on which democratic organizational practices, and democratic business ethics, are understood; and how does the strategic challenge of sexual difference enable us to foster and cultivate a more expansive and radicalized notion of difference in organizations that responds to an intercorporeal and embodied ethics? The remainder of the paper offers a number of observations that move these discussions forward to enable a richer theorization of gendered difference in democratic business ethics.

Feminist politics of difference offer ways of disturbing organizations, as intimated earlier, pushing beyond constructed categories assigned to us and engaging in a politics of disturbance of organizational order through critique and resistance to the sovereignty of business. Accordingly, corporate masculinity "is not so much a rejection of the feminine, but more a co-optation of it for the purpose of masculine public glory" where the feminine "is not absent, but rather is rendered as being at the service of the masculine" (Rhodes and Pullen 2018, p. 494).

The embodied ethics and politics of activism seen in feminist movements, such as \#MeToo and Sisters Uncut, have a dialogic and often problematic relation to formal organizations such as corporations and the State. Approaches that seek to explore the "embodied, practical and cooperative character of the self-other relation" (Harding et al. 2012, p. 57, cited in Tyler 2018, p. 50) and recognition of never fully knowing the Other (Ahmed 2002) require more attention in business ethics, especially the complex relationship between feminist ethics, direct action and the possibilities of a democratic ethics of organization. This challenges the idea that "the corporation has extended the market, if not the civil freedoms on which it was predicated" (Fermon 1998, p. 123). Sexual difference offers a contestation of corporate masculinity and sovereignty and attention to embodied differences that are constitutive and generative of other differences that need to be addressed (Gherardi 2010).

A democratic culture of difference enables fruitfully rethinking democratic business ethics by reconfiguring feminine difference where collective action disturbs corporate sovereignty in business ethics. Irigaray's elaboration of sexual difference, as developed earlier, establishes recognition and respect for difference as "prior to productive and generative relations" between genders (Fermon 1998, p. 121). These politics defy easy categorization and offer no immediate solutions (Fermon 1998) but dissensus, thought through this lens, is not negative but "a productive means through which democracy can be pursued." (Rhodes 2016, p. 1510).

"Feminism still needs a theory of sexual difference, but a theory that is more dynamic, more democratic and more ethical-a theory capable of foregrounding not only the futurity of democracy and the antagonistic differences among women but also the ethical respect for alterity in all its forms" (Ziarek 2001, p. 152). This prompts us to acknowledge the ethical and political dimensions of difference in its multitude as central to a democratic business ethics. For radical democracy in feminist social movements, "The public sphere is understood as a contested space where agonistic differences should come into productive conflict without recourse to any hope of ideal consensus". (Rhodes 2016, p. 1510). These social movements challenge individual sovereignty and direct public attention to inequality but beyond this offer the possibility of a collective, democratic ethics of openness and appreciation of self-other relations. They offer hope in bleak times and show the vibrancy of feminist activism and the political spaces and strategies used to frame, structure and enact social change (Grosser and McCarthy 2018).

Difference is never accomplished or completed but involves reasserting feminine difference and highlights the importance of alterity, involving "obligation for the Other and the agency of the subject, between responsibility and the struggles against sexist, racist and class oppression, and finally, between the desire for justice and embodiment, affect, and sexuality." (Ziarek 2001, p. 6). Embodied ethical relations (Thanem and Wallenberg 2015) are central to this endeavour and reconceptualises ethical obligation without collapsing into unconditional responsibility or "an indifferent struggle of heterogenous forces without ethical stakes" (Ziarek 2001, p. 6).

A democratic culture of difference, understood through sexual difference, thus offers a conceptual framework 
through which to re-imagine the constitutive exclusions faced by marginalized or vulnerable groups where "Our desire to install a new kind of social system does not preclude us from living in the one that exists" (Irigaray 1993a, b, cited in Fermon 1998, p. 122). Beyond this, an ethics of dissensus enables the confrontation of power and political differences without "the utopian vision of justice transcending antagonisms of race, class, sexuality, and gender" (Ziarek 2001, p. 6). Valuing dissensus as a source of ethics, one that can account for "vulnerability to difference without assuming that such difference can be known", is central to the development of a practical and democratic business ethics (Rhodes 2016, p. 1512).

\section{Concluding Thoughts}

Discourses around women's empowerment and corporate ethical discourses of equity, such as the business case for gender equality, have arguably come to be seen as part of the corporate business ethics and CSR architecture of organizations. However, critiques of these approaches highlight their selective recognition of difference and studies clearly demonstrate how difference is adopted in problematic ways in formal organizations (Grosser and Moon 2017; Karam and Jamali 2015). Feminist social activism and protest offer a new way of understanding gendered differences in business ethics, where complex events and the tensions and challenges that arise remind us "what is possible when feminists assemble the combined forces of our bodies, practices, and ethics" (Tyler 2018, p. 60).

The two cases discussed present opportunities to understand the complex dynamics of dissent and radical democracy based on intercorporeal and embodied differences that offer "a better place to locate business ethics...in practical modes of dissent and disturbance to corporate sovereignty arising within civil society." (Rhodes 2016, p. 1509). This could be termed a democratic ethics of difference that takes into account gendered differences and reconceptualises ethical obligation as a challenge to corporate business ethics. Differences can be tactically and reflexively mobilised in rethinking radical forms of democracy, as explored earlier. This tactical reassertion demands questioning the basis on which the feminine is constructed in organizations, it necessitates and leads to an ethical questioning from which arise an ethics of becoming and ethos of alterity, in Ziarek's terms. It requires an understanding of negation and the impossible: "what divides, as a negativity, is also that which can bring us close: 'I defend the impossible' [Irigaray 1996] " (Fermon 1998, p. 122).

We can hope that new possibilities emerge from this endeavour. Activist politics at the heart of feminism have much to teach us about how difference is constructed, managed or even negated in formal and informal organizations and this advances thinking about the importance of and tensions within democratic business ethics. Tyler (2018, p. 62) recognises that "what is needed, politically and ethically, is a destabilization of the regulatory ideals that shape" difference in organizations. Feminist politics and activism through movements, protests and collective acts promise embodied, ethical and political practices that challenge normative regimes that categorise difference (see Ashcraft 2009). The latter is an "an exploitation of our basic relationality, foreclosing rather than supporting genuine recognition (Tyler 2018, p. 62) and impeding nonappropriative self-other relations. The new ways of organizing seen in contemporary feminist movements challenge systems of oppression and the constitutive exclusions faced by different women with the promise of hope and vulnerability of the embodied and generous ethical relation. Many of us know, when we name a problem, we often become the problem (Ahmed 2015). This means instaling ourselves as problems. The power of dissent and antagonism at the heart of these movements suggest perhaps, beyond Irigaray, a literal labouring against the negative where the disavowal of women's existence and the negation of the feminine can be recovered as a source of invention and possibilities through the power of dissent, critique and protest.

Acknowledgements This article has benefitted from the close attention and insightful critique of the reviewers and special issue editors. Particular thanks go to Alison Pullen and Melissa Tyler for their close attention to the theoretical ideas and for their continued support and wise counsel. I dedicate this article to a new addition to my family who I hope will inherit the fire to fight injustice and live in better times.

Funding This article received no funding.

\section{Compliance with Ethical Standards}

Conflict of interest Sheena J. Vachhani declares that he/she has no conflict of interest.

Research Involving Human Participants and/or Animals This article does not contain any studies with human participants or animals performed by any of the authors.

Open Access This article is licensed under a Creative Commons Attribution 4.0 International License, which permits use, sharing, adaptation, distribution and reproduction in any medium or format, as long as you give appropriate credit to the original author(s) and the source, provide a link to the Creative Commons licence, and indicate if changes were made. The images or other third party material in this article are included in the article's Creative Commons licence, unless indicated otherwise in a credit line to the material. If material is not included in the article's Creative Commons licence and your intended use is not permitted by statutory regulation or exceeds the permitted use, you will need to obtain permission directly from the copyright holder. To view a copy of this licence, visit http://creativecommons.org/licenses/by/4.0/. 


\section{References}

Ahmed, S. (2002). This other and other others. Economy and Society, $31(4), 558-572$.

Ahmed, S. (2015). Introduction: Sexism-A problem with a name. New Formations, 86, 5-13.

Ashcraft, K. (2009). Gender and diversity: Other ways to 'make a difference'. In M. Alvesson, T. Bridgman, \& H. Willmott (Eds.), The Oxford handbook of critical management studies (pp. 304-327). Oxford: Oxford University Press.

Bennett, J. (2018). The \#MeToo Moment: What's Next?. The New York Times. Retrieved June 15, 2018, from https://www.nytim es.com/2018/01/05/us/the-metoo-moment-whats-next.html.

Borgerson, J. (2007). On the harmony of feminist ethics and business ethics. Business and Society Review, 112(4), 477-509.

Burton, B., \& Dunn, C. (1996). Feminist ethics as moral grounding for stakeholder theory. Business Ethics Quarterly, 6(2), 133-147.

Butler, J. (1993). Bodies that matter. London: Routledge.

Charles, N., \& Wadia, K. (2017). New British feminisms, UK Feminista and young women's activism. Feminist Theory, 19(2), $165-181$.

Cheah, P., \& Grosz, E. (1998). Of being-two-An introduction. Diacritics, 28(1), 2-18.

Dale, K. (2001). Anatomising embodiment and organization theory. London: Palgrave Macmillan.

Dale, K., \& Latham, Y. (2015). Ethics and entangled embodiment: Bodies-materialities-organization. Organization, 22(2), $166-182$

Deardon, L. (2015). Trafalgar Square fountains dyed blood red as Sisters Uncut demonstrators protest against women's refuge cuts. The Independent, 28th November 2015. Retrieved April 29, 2019, from https://www.independent.co.uk/news/uk/home-news/trafa lgar-square-fountains-dyed-blood-red-as-sisters-uncut-demon strators-protest-against-womens-a6752861.html

Deutscher, P. (2002). A politics of impossible difference-The Later Work of Luce Irigaray. New York: Cornell University Press.

Fermon, N. (1998). Women on the global market-Irigaray and the democratic state. Diacritics, 28(1), 120-137.

Flynn, E. (2019). \#MeToo and race: how double oppression can have serious consequences. NITV 3rd May 2019. Retrieved May 4, 2019, from https://www.sbs.com.au/nitv/article/2019/05/03/metoo -and-race-how-double-oppression-can-have-serious-consequenc es.

Fotaki, M. (2011). The sublime object of desire (for knowledge): Sexuality at work in business and management schools in England. British Journal of Management, 22, 42-53.

Fotaki, M. (2013). No woman is like a man (in academia): The masculine symbolic order and the unwanted female body. Organization Studies, 34(9), 1251-1275.

Fotaki, M., Metcalfe, B., \& Harding, N. (2014). Writing materiality into management and organization studies through and with Luce Irigaray. Human Relations, 67(10), 1239-1263.

Fuss, D. (1992). Essentially speaking': Luce Irigaray's language of essence. In N. Fraser \& S. L. Bartky (Eds.), Revaluing French feminism: Critical essays on difference, agency and culture (pp. 94-112). Bloomington, IN: Indiana University Press.

Gatens, M. (1999). Power, bodies and difference. In J. Price \& M. Shildrick (Eds.), Feminist theory and the body (pp. 227-234). Edinburgh: Edinburgh University Press.

Gherardi, S. (2010). Feminist theory and organization theory: A dialogue on new bases. In H. Tsoukas \& C. Knudsen (Eds.), The Oxford handbook of organization theory. Oxford: Oxford University Press
Grosser, K. (2016). Corporate social responsibility and multi-stakeholder governance: Pluralism, feminist perspectives and women's NGOs. Journal of Business Ethics, 137(1), 65-81.

Grosser, K., \& McCarthy, L. (2018). Imagining new feminist futures: How feminist social movements contest the neoliberalization of feminism in an increasingly corporate-dominated world. Gender, Work and Organization, . https://doi.org/10.1111/gwao.12267.

Grosser, K., \& Moon, J. (2005). Gender mainstreaming and corporate social responsibility: Reporting workplace issues. Journal of Business Ethics, 62(4), 327-340.

Grosser, K., \& Moon, J. (2017). CSR and feminist organization studies: Towards an integrated theorization for the analysis of gender issues. Journal of Business Ethics, 155(2), 321-342.

Harding, S. (1987). Feminism and methodology. Bloomington, IN: Indiana University Press.

Harding, N., Ford, J., \& Fotaki, M. (2012). Is the 'F'-word still dirty? A past, present and future of/for feminist and gender studies in Organization. Organization, 20(1), 51-65.

Hekman, S. (Ed.). (1999). Feminism, identity and difference. Frank Cass: Essex.

Hemery, S., \& Singh, G. (2019). Feminist lawyers of South Asia rally to aid of \#MeToo survivors. The Guardian, 4th May 2019. Retrieved May 4, 2019, from https://www.theguardian.com/world /2019/may/04/feminist-lawyers-south-asia-rally-to-support-ofmetoo-survivors.

Höpfl, H. (2000). The suffering mother and the miserable son: Organizing women and organizing women's writing. Gender, Work and Organization, 7(2), 98-105.

Irigaray, L. (1985a). Speculum of The Other Woman. Trans GC Gill. New York: Cornell University Press.

Irigaray, L. (1985b). This Sex Which is Not One. Trans. C. Porter. New York: Cornell University Press.

Irigaray, L. (1993a). An Ethics of Sexual Difference. Trans C. Burke and G.C. Gill. London: Athlone.

Irigaray, L. (1993b). Je, Tu, Nous - Towards a Culture of Difference. Trans. A. Martin. London: Routledge.

Irigaray, L. (1994). Thinking the Difference-For a Peaceful Revolution. Trans. K. Montin. London: Athlone.

Irigaray, L (1996). I Love to You-Sketch of a Possible Felicity in History. Trans A. Martin. London: Routledge.

Irigaray, L (2000a). To Be Two. Trans. M.M. Rhodes and M.F. CocitoMonoc. London: Athlone.

Irigaray, L (2000b). Democracy Begins Between Two. Trans. K. Anderson. London: Athlone.

Just, S. N., \& Muhr, S. L. (2018). "Together we rise": Collaboration and contestation as narrative drivers of the Women's March. Leadership, 15(2), 245-267.

Karam, C. M., \& Jamali, D. (2015). A cross-cultural and feminist perspective on CSR in developing countries: Uncovering latent power dynamics. Journal of Business Ethics, 142(3), 461-477.

Keenan, J., Kemp, D., \& Ramsay, R. (2014). Company-community agreements, gender and development. Journal of Business Ethics, 135(4), 607-615.

Kozinets, R. (2015). Netnography: Redefined (2nd ed.). London: Sage.

Kwai, S. (2015). Why I protested with Sisters Uncut at the Suffragette premiere. The Independent 8th October 2015. Retrieved April 29, 2019, from https://www.independent.co.uk/voices/why-i-prote sted-with-sisters-uncut-at-the-premiere-of-suffragette-a6685686. html.

Lather, P. (1991). Getting smart-Feminist research and pedagogy with/in the postmodern. London: Routledge.

Liedtka, J. (1996). Feminist morality and competitive reality: A role for an ethic of care? Business Ethics Quarterly, 6(2), 179-200.

Martin, A. (2003). Introduction-Luce Irigaray and the culture of difference. Theory, Culture and Society, 20(3), 1-12. 
Metcalfe, B. (2005). Exiling the feminine? Re-imagining Luce Irigaray in the philosophy of organization. Paper presented at the Critical Management Studies Conference 2005.

Munar, A. (2018). Can I kiss you? CBS Wire. Retrieved March 18, 2019, from http://cbswire.dk/can-i-kiss-you/.

Munro, E. (2013). Feminism: A fourth wave? Political Insight, 4(2), 22-25.

O'Hagan, E.M. (2015). Groups such as Sisters Uncut are the modern suffragettes. The Guardian, 8th October 2015. Retrieved April 29, 2019, from https://www.theguardian.com/commentisfree/2015/ oct/08/sisters-uncut-suffragette-film-premiere-women.

Oseen, C. (1997). Luce Irigaray, sexual difference and theorizing leaders and leadership. Gender, Work and Organization, 4(3), $170-184$

Ozkazanc-Pan, B. (2018). On agency and empowerment in a \#MeToo world. Gender, Work and Organization, 26(8), 1212-1220.

Pedwell, C. (2014). Affective relations-The transnational politics of empathy. Basingstoke: Palgrave.

Pullen, A., \& Rhodes, C. (2014). Corporeal ethics and the politics of resistance in organizations. Organization, 21(6), 782-796.

Pullen, A., \& Rhodes, C. (2015). Ethics, embodiment and organizations: Editorial introduction. Organization, 22(2), 159-165.

Pullen, A., Rhodes, C., \& Thanem, T. (2017). Affective politics in gendered organizations: Affirmative notes on becoming-woman. Organization, 24(1), 105-123.

Pullen, A., \& Vachhani, S. (2018). A leadership ethics of sexual difference? In A. Bols $\varnothing$, S. O. Sørensen, \& S. H. B. Svendsen (Eds.), Bodies, symbols and organizational practice: The gendered dynamics of power. London: Routledge.

Rhodes, C. (2014). Ethical anarchism, business ethics and the politics of disturbance. Ephemera: Theory and Politics in Organization, 14(4), 725-737.

Rhodes, C. (2016). Democratic Business Ethics: Volkswagen's emissions scandal and the disruption of corporate sovereignty. Organization Studies, 37(10), 1501-1518.

Rhodes, C., \& Pullen, A. (2018). Critical business ethics: From corporate self-interest to the glorification of the sovereign pater. International Journal of Management Reviews., 20(2), 483-499.

Robinson, J. (2000). Feminism and the spaces of transformation. Transactions of the Institute of British Geographers, 25(3), 285-301.

Rottenberg, C. (2017). Can \#MeToo go beyond white neoliberal feminism? Aljazeera. Retrieved March 18, 2019, from http://www. aljazeera.com/indepth/opinion/metoo-white-neoliberal-feminism171213064156855.html.

Seales, R. (2018). What has \#MeToo actually changed? BBC News 12th May 2018. Retrieved June 15, 2018, from https://www.bbc.co.uk/ news/world-44045291.
Spratt. (2016). How Sisters Uncut Are Changing The Way Politics Is Done Meet the feminist activists that you didn't know existed, Grazia. accessed Retrieved April 30, 2019, from https://graziadail y.co.uk/life/real-life/sisters-uncut/.

Thanem, T., \& Wallenberg, L. (2015). What can bodies do? Reading Spinoza for an affective ethics of organizational life. Organization, 22(2), 235-250.

Tyler, M. (2018). Re-assembling difference? Rethinking inclusion through/as embodied ethics. Human Relations. https://doi. org/10.1177/0018726718764264.

Vachhani, S. (2012). The subordination of the feminine? Developing a critical feminist approach to the psychoanalysis of organizations. Organization Studies, 33(9), 1237-1255.

Vachhani, S. (2014). Always different? Exploring the monstrous-feminine and maternal embodiment in organization. Equality, Diversity Inclusion, 33(7), 648-661.

Vachhani, S. J. (2018). Rethinking the politics of writing differently through écriture féminine. Management Learning, 50(1), 11-23.

Vachhani, S., \& Pullen, A. (2019). Ethics, politics and feminist organizing: Writing feminist infrapolitics and affective solidarity into everyday sexism. Human Relations, 72(1), 23-47.

Walby, S. (2011). The future of feminism. Cambridge: Polity.

Weiss, G. (1998). Body images: Embodiment as intercorporeality. London: Routledge.

Whitford, M. (1991). Luce Irigaray-Philosophy in the feminine. London: Routledge.

Grosz, E. (1994). Volatile bodies: Toward a corporeal feminism. Bloomington, IN: Indiana University Press.

Zanoni, P., Janssens, M., Benschop, Y., \& Nkomo, S. (2010). Unpacking diversity, grasping inequality: Rethinking difference through critical perspectives. Organization, 17(1), 9-29.

Ziarek, E. P. (1998). Towards a radical female imaginary-Temporality and embodiment in Irigaray's ethics. Diacritics, 28(1), 59-75.

Ziarek, E. P. (2001). An ethics of dissensus-Postmodernity, feminism and the politics of radical democracy. California: Stanford University Press.

Publisher's Note Springer Nature remains neutral with regard to jurisdictional claims in published maps and institutional affiliations. 